\title{
Bronze Incense Burner in the form of an Equestrian Statue as the Unique Sassanid Art Found in Azerbaijan
}

\author{
Baghirov Elshad* \\ Department of History, Baku State University, Azerbaijan
}

*Corresponding author: Baghirov Elshad, Department of History, Baku State

University, Azerbaijan.

Received Date: January 13, 2020

Published Date: February 26, 2020

\begin{abstract}
Present article is dedicated to the unique found of the last century in Azerbaijan territory it is bronze incense burner in the form of an equestrian statue. This historical monument concerns to Iranian Sassanid Empire, present article analyzes the comparative knowledge and identification of this incense burner as the matter of fact the images of this monuments is the young King of the Kings Khosrow II Parviz" Victoriuos" also thereupon gives briefly overview about Khosrow II, gives a broad analysis of the problem of identifying the figurine and its significance for Azerbaijan as one of historically keepers of Persian art of Pre- Islamic periods of the Sassanids Empire.
\end{abstract}

Keywords: Pre-Islamic period; Toreutic; Persian art; Azerbaijan; Sassanid empire; Khosrow II parviz; Caucasus albania; Jevanshir mehranid; Equestrian statue; Bronze incense burner

\section{Introduction}

Among of the various cultural monuments reflecting the culture, ideology and artistic tastes of the peoples in ancient times, significance place is taken by the art utensil made of precious metals and bronze-toreuties. The art of metalwork is one of the leading branches of the decorative and applied art, having a centuries old history and sustainable element of culture before Islamic periods of Iran [1].

Studies of Persian arts before Islamic periods is occupy a significance place in domestic and as in foreign historical and archaeological science literature it is the monuments of arts toreutic as the historical source which is helps in studying of the sociopolitical, cultural, trade and economic issues of life in interested period. Particular historical importance is the monuments of ornamental applied arts, including toreutic they are acquired when they were discovered in archaeological complexes. These unique finds are important indicator of the pervasion the elements of the Persian culture, their mode of life and the artistic tastes of the ancient Iran, played significant role in the development of Persian art before Islamic epoch. Present article is a generalizing historical and archaeological study of the figurine bronze incense burner in the form of an equestrian statue from Azerbaijan, associated with the periods of Sassanid reign (Figure 1).
As result of analysis to such material like bronze incense burner in the form of an equestrian statue serves was attempted to reveal the role and place of the bronze incense burner in the history of both Iran and Azerbaijan pre-Islamic period. Undoubtedly, the Persian art of pre-Islamic periods influenced to Azerbaijan, as the matter of fact it is reflecting objectively role. Azerbaijan is one of the custodians of pre-Islamic heritage, the artifacts like bronze incense burner in the form of an equestrian statue is historical source and archaeological monument has certain valuable in solving number of the hard to reached issues of the ancient history of Azerbaijan starting from the Achaemenid period till to Arab conquest [2].

Present article is focused on the figurine of this bronze incense burner, as the primary source found in the territory of Azerbaijan this is the random find as artifact of the Sassanid period was transferred and still preserved in State museum of Russian Federation Hermitage, St. Petersburg same copy of this artifact is in the Azerbaijan National Museum of History (Figure 2). The analysis as material, served on the basis in which was made attempt to reveal the role and place of bronze incense burner and its identification of equestrian statue as the unique Sasanian toreutic art found from Azerbaijan [3]. 

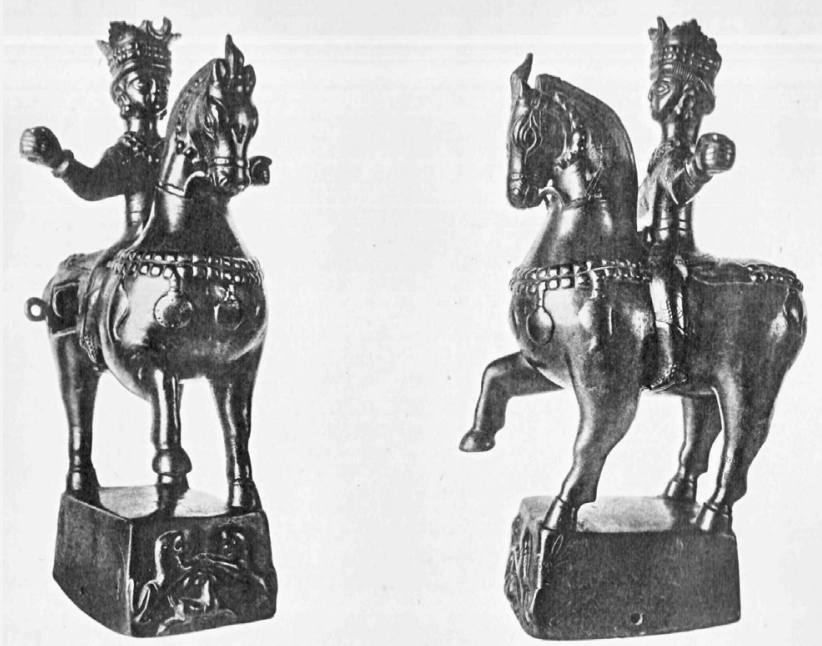

Figure 1: Bronze incense burner in the form of an equestrian statue from the book - Orbeli I.A. Trever K. V. Sasanidskiy metal - L., 1935, table 85 .

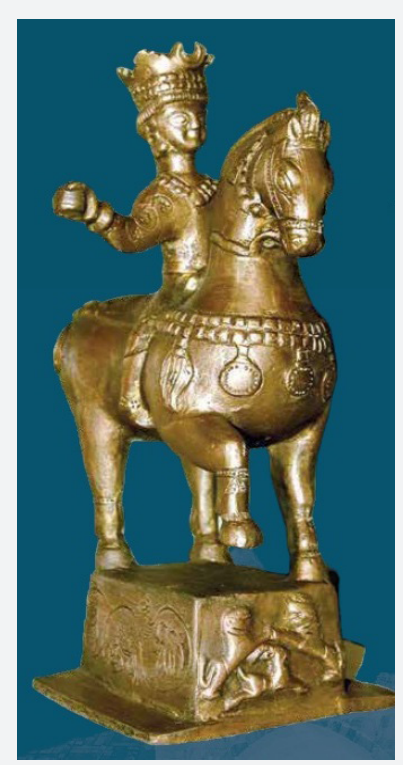

Figure 2: Sculptural Arts of Caucasian Albania (National Museum of History Azerbaijan) Baku, 2019 - Cover.

\section{Detection Conditions and Comparative Knowledge} of the Bronze Incense Burner from Azerbaijan

The bronze incense burner in the form of an equestrian statue from Azerbaijan according to studied period there can be divided into the two groups:

I. Item detected as a result of research as an archaeological artifact, according to the rule of different types of the burial and objects, accidentally discovered under the various circumstances.

II. The attribution of this item (dating, place of manufacture, the ways of penetration in Azerbaijan, identification of the equestrian statue is extremely difficult, requires for need carefully approaches.

After many years of the last century, the objects of artifact, also same bronze incense burner in the form of an equestrian statue from Azerbaijan as toreutic art were represented exclusively as random finds and despite of the fact among of them were genuine masterpieces of the metalwork art pre0Islamic period based on them it was difficult to find true the role and place of art utensils from Azerbaijan. In the post II world war period, as result of extensive archaeological research there were gradually certain the numbers of Persian artifacts of pre-Islamic art of toreutics were accumulated $[4,5]$.

The most numbers of Persian arts are preserves at the State Hermitage Museum of Saint-Petersburg. For example, a silver jug acquired from Azerbaijan, Baku city in 1902 was accidentally finds. Silver jug (Figure 3) for the first time was published in the work of "“East Silver Atlas of Ancient Silver and Gold Plate" by Smirnov YI in 1909 year [6], next book "Oriental silver" was published by Orbeli IA and Trever KV [7] in their collaboration work "The album of Sasanian toreutics" in 1935. 


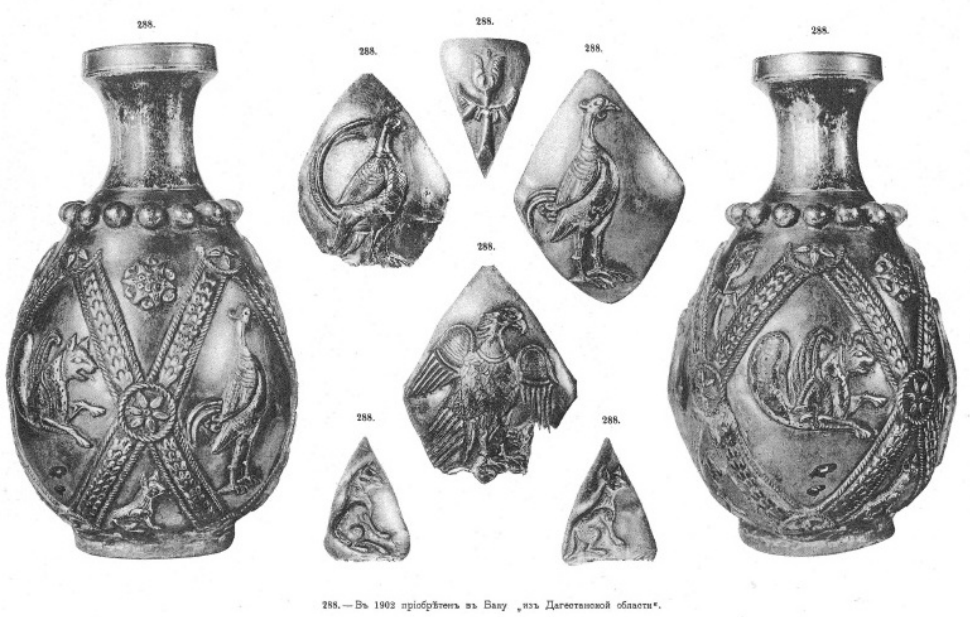

Figure 3: From the books "East Silver Atlas of Ancient Silver and Gold Plate". Publications of the Imperial Archaeological Organization - St. Petersburg. 1909..

Subsequently Trever KV [8] erroneously suggested the possibility of the Dagestan origin of this silver jug. However, the presence of numerous analogical silver jugs among the toreutics of Sassanid Iran in VI-VII centuries A.D. giving reason for including this silver jug to the numbers of products of this particular circle, but not Dagestan. It is no coincidence that silver jug was also published by Lukonin VG [9] as the pattern of pre-Islamic toreutics of Iran in VI century. But let's to focused on the unique Sassanid art the bronze incense burner in the form of an equestrian statue which was purchased in 1901 from an antique dealer, who in its turn bought it in Nakhichevan, Azerbaijan region.

The statuette for the first time was shown in 1922 year at the temporary exhibition of Sasanian antiquities in the Hermitage. Devoting to this exhibition in a short article professor Orbeli IA [10] noted its historical importance as the artifact monument also he attributed it to the numbers of the objects to Sassanid plastic. Since that time bronze incense burner was included among the numbers object to Sasanian art and was shown at the London exhibition of Sassanid antiquities then was released in a multi-volume review of ancient Iranian art (Figure 4).

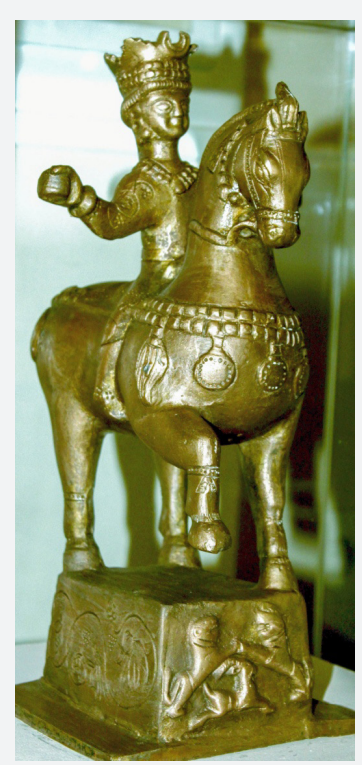

Figure 4: Figure a copy of the bronze incense burner sculpture of Khosrow II (591-628) at the National Museum of History Azerbaijan. The original artifact is kept at the Hermitage.

At the end of the 50 -th of the last century, Trever KV in its fundamental research on the history and art of Caucasian Albania hypothesized that this bronze equestrian figurine personifies the image of the ruler of Caucasian Albania Javanshir from dynasty of Mehranids (637-680). But if Trever KV expressed hypothesized about this fact next followers are subsequent Azerbaijanis researchers also supported this point of view which was sounded the same fact about bronze incense burner sculptural depicting Javanshir Mehranid [11]. 
"Khosrow the Victorious" (591-628) in Image of the Bronze Incense Burner in the form PF an Equestrian Statue

Khosrow II (Chosroes II in classical sources; Middle Persian: Husrō(y)), also known as Khosrow Parviz (New Persian: Khosrow Parviz, "Khosrow the Victorious") was the last great Sasanian king (shah) of Iran, ruling from 590 to 628, with an interruption of one year [12].

Khosrow II was the last king of the Sasanian dynasty. He is a giant figure who towers over the Middle East in the last few decades before the coming of Islam. The principal extant in Armenia of the period, written in Armenia in the early 650, was appropriately entitles The History of Khosrow by Armenian historian Sebeos. Khosrow II was held personally responsible for the destruction of the old world order. He lost his throne, then recovered it with Roman help and a decade later, went to emulate the feats of the Achaemenids conquering the rich Roman provinces of the Middle East including Egypt before a sudden vertiginous fall at the very apogee of his career. He is eighthly accorded a great deal of space in the Shah-Name.

The Sassanian king of kings (590-628 AD), who became famous due to the magnificence of his court and its excessive expenses. At the beginning of his reign, Khosrov II suppresses the rebellion of the candidate Bahram VI Chubin with the help of the Byzantines and the Emperor of Mauritius (where his nickname Aparvez Victorious comes from). In 600, Khosrov launched a campaign against the Lachimids. Their king An-Noman III fell into the hands of the Persians and was assassinated in prison-602 year. Two years later, Sassanid was defeated near Kufa (territory of Iraq) from alliance of Arab tribes. Under Khosrow II rule, Sassanid Empire reached its maximum territory. In 603 year after the assassination of Mauritius General Foka, Khosrow II unleashed a war against Byzantium [13].

In 604 year Shahanshah arrives in Chalkedon and since 604 rules over Syria. In 605 kings of kings Khosrow Victorious occupied Edessa, Amida, Aleppo and Antioch in 611, Damascus and Tara fell in 613. In 619 the shahnshah subjugates Egypt and in 626 besieges Constantinople with Avars. In 614, he carries the Holy Cross from Jerusalem to Ctesiphon [14].

But soon Heraclius (626-628) years defeats the Sassanid army at Nineveh and forces him to abandon the conquered territories. Khosrow II was overthrown and killed by his son Shiroie during the rebellion by the nobility in 628 year. Soon after his death, Arabs began first attacked to Sassanid Empire in 633 year. The novel "Khosrow and Shirin", Shirin is one of his beloved spouses (who was monophysite Christian) of the Azerbaijani-Persian poet Nizami XII century makes his, popular.

As one of the main characters of the poem "Shahnameh" written by the Firdowsi (935-1020) he devoted 4,135 beits to Khosrow II more than one third of the Sasanian part of poem which contemporary scholars in contrast to other parts are called historical. Khosrow II as it were between two extremes, Firdowsi describes his personal traits as bravery and chivalrous nobility, concern for the welfare of the Sassanid state but also love pleasure as well as combined in this image of a sybarite, philanthropist and very careful wise politician. Like Khosrow Anushirewan, he had brilliant courtyard, but these are mostly were not scholars, they were predominantly poets, musicians, builders [16].

His character is toughened towards the end of the Sassanid Empire life, undertaking for prestigious purposes, he will prepare his terrible end. The evil committed by him at the beginning of his reign, turns against him in his last days (Figure 5).

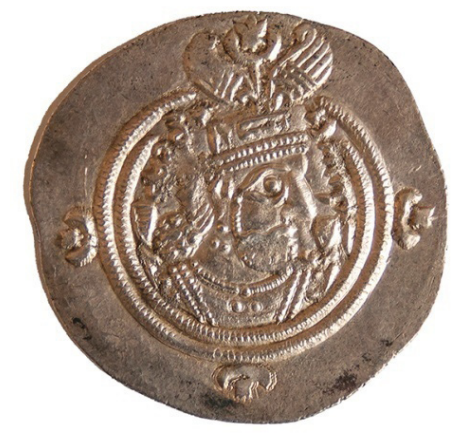

Figure 5: Figure picture of the silver coin of Khosrau II Parviz minted in Nakhchewan - Azerbaijan.

Such figure of Khosrow II was perhaps not very consistent it what there been researched about him from numerous and multilingual sources devoted to this periods of Sassanid history. In the numerous sources and monuments of Persian literature, the "Victorious" King of the Kings Khosrow II is always inseparable from surrounding luxury, sophistication and power as well as from the beautiful Shirin whose personification is the cultural tradition of Iran in Islamic culture. Exceptional focusing in contiguity with cultural traditions of Iran in Pre-Islamic period is purify expressing by the great humanities Persian classic poet Nizami Ganjevi (11441209), his romantic work "Khosrow and Shirin" there are revealing the picture of love by the Shahinshah Khosrow II to his love and devotion to Shirin (Figure 6). 


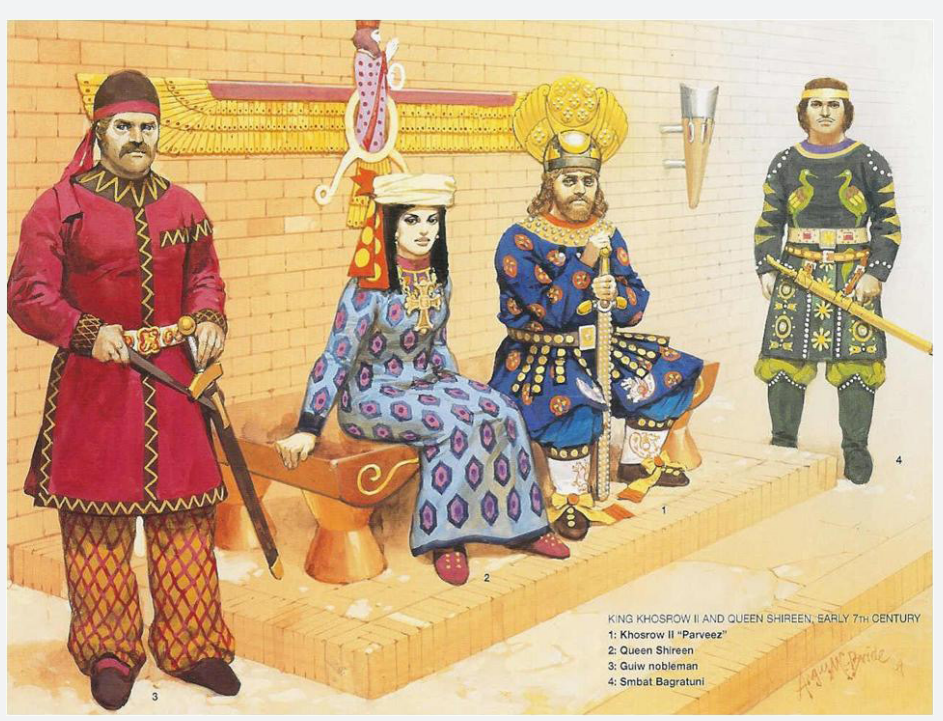

Figure 6: Figure of the court of Khosrow II in the early 7th century AD. From left to right - Guiw Nobleman, Queen Shireen, Khosrow II "Parveez" and Smbat Bagratuni. The latter defeated a massive Turco-Hun force from Central Asia in 619 AD - he then drove the remnants of the invaders back into the depths of Central Asia. Bagratuni achieved this success just as General Shahrbaraz was invading Egypt in that same year (619 AD) consult: pp. 255-257.

This love story unfolds around historical events overthrown Sassanid king Hormizd during the uprising accession to the throne of the son Khosrow II in 590 year, who probably participated in uprising rebellion of the commander Bahram Chubin against the new king and appealing by Khosrow II for the help to Byzantine Emperor Mauritius (Maurice) 582-602. These events are described detailed, above mentioned poem by the genius Firdowsy in "Shahnameh". But Nizami focused on the relationship between Khosrow and Shirin, Persian poet noted that sources were manuscripts from Barda, ancient capital of Azerbaijan today which used called Arran [17-19].

Shirin is historical real person, Byzantium historian Theophylact Simocatta cites the text from Khosrow II's letter in Grecian language abou accompanied the donation to the Basilica of St. Serius in Reza, present Syria. Both text were cited by the Byzantium historian Evagrius Scholasticus. In one of the letters relating to the 593 year there are talking about Shirin's pregnancy who accompanied to Khosrow II on a trip to Byzantium. In this document letter Khosrow II wrote that although Shirin is a Christianity, King cannot legally marry, but he ignored this law in gratitude to Byzantium he keeps Shirin among his wives as legal. According to this text a number of historian's beliefs that Shirin was concubine for temporary times, Khosrow II sign of devotion to Byzantium broke Mazdean law and took Shirin in his legal wife. Great Armenian historian Sebeos lived in VII century A.D. also mentioned about Shirin as influential wives of Khosrow II also mentioned about her living place from Khuzistan. Among ancient sources there are two Syrian chronicles, according origin Shirin was "Aramaic" that is she was from the region of Beth Aramai, today is Iraq.

\section{Identification Analysis of Bronze Incense Burner in the Form of an Equestrian Statue}

Bronze incense cast figurine on a quadrangular pedestal is depicting a rider on a powerful horse. The figures of equestrian statue are hollow in the side horse there is a hole where odorous herbs and coals were put inside. Special holes in the horse's mane and in the riders', crown serve the entrancing aromatic smoke. The height of the incense burner is $35 \mathrm{~cm}$. It is consisting of the three elements: a pedestal, horse, rider (Figure 7).

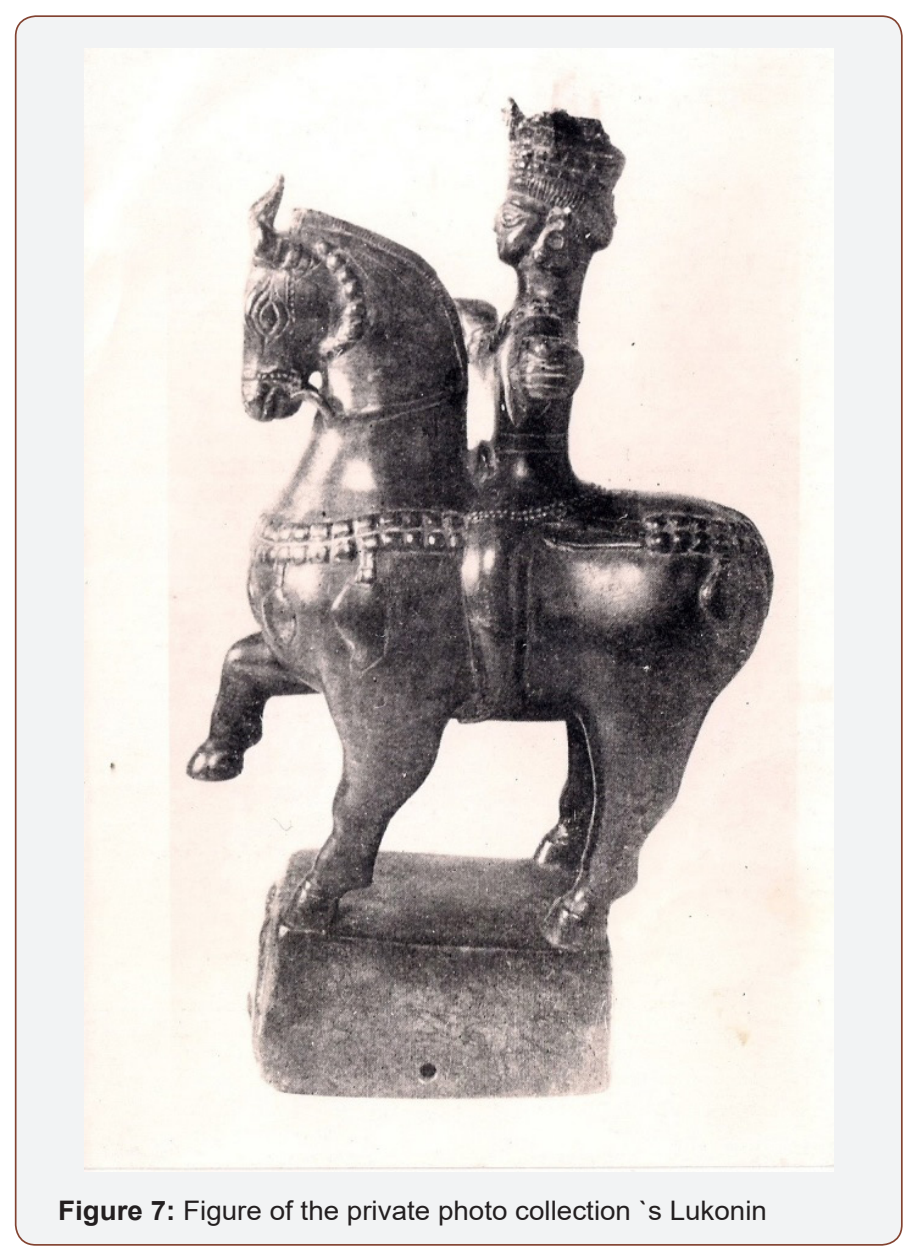


The pedestal in the form of a slightly tapering parallelepiped in the upper part has a height of the $6 \mathrm{~cm}$. On the front side there is a cast of the image two lions standing on their hind legs and resting against each other by the front legs. Between the lions there is a gazelle is depicted in a fast running pose (Figure 8).

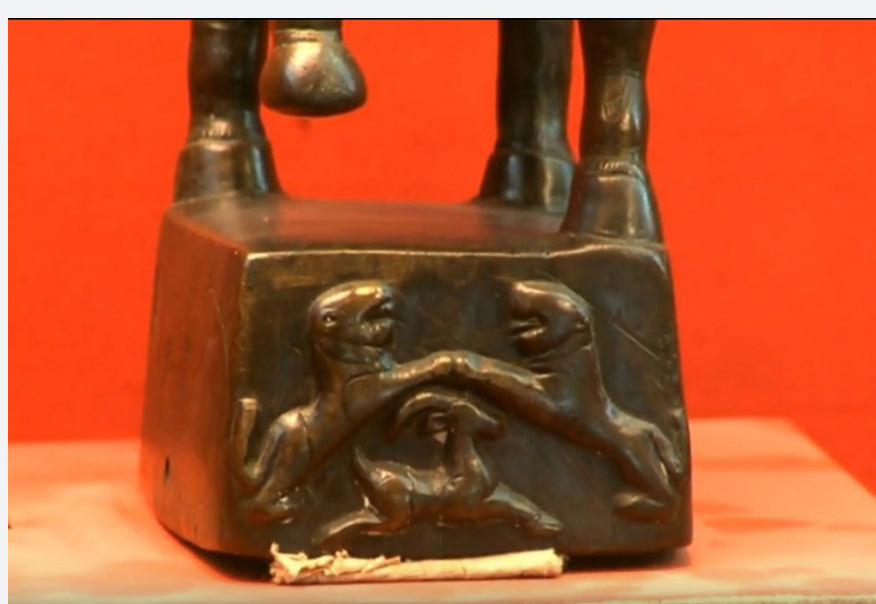

Figure 8: Fragment of the bronze incense burner cameo from the documentary movie about Hermitage the hall of Orient culture.

The details of the image of individual features of the animals (manes, wool, etc) are highlighted by engraving. The back side pedestal is smooth. The left side has an engraved image of a winding vine with leaves and bunches of grapes. In the bends of the vine there is an image of elephant and fox reaching for grapes. On the opposite side is an engraved image of a man hunting for a lion. With special strokes, imitations of mountainous areas depict of the trees.
The lion is depicted at the time of the jump on the hunter. The figure of a lion is conveyed in the correct proportions. The hunter, on the contrary is depicted extremely disproportionately. A massive head a thickened neck and a wide chest do not fit with thin and short arms and legs. In the hunter's right hand is dagger, in the left is an ax (Figure 9).

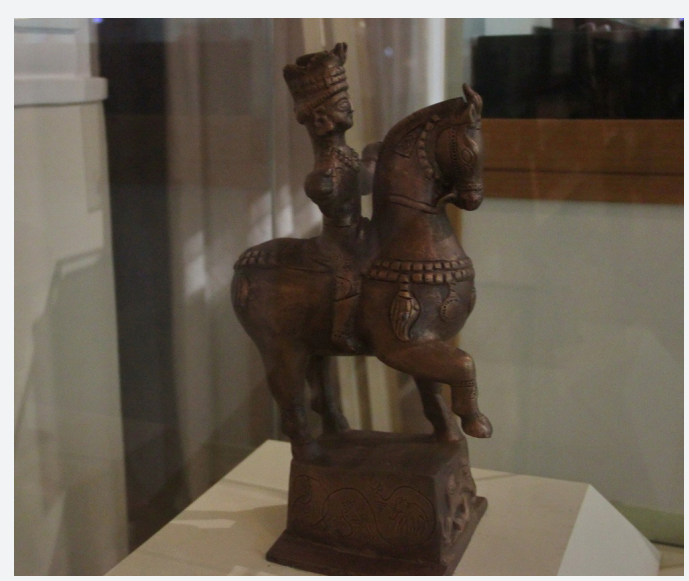

Figure 9: Figure from another side of bronze incense burner private picture from Hermitage museum.

The horse is depicted in a static pose with the front foot raised. Short thickened legs a wide chest and powerful dome make the entire horse figure weighty. On the horse's head shah is characteristic decoration of the Sassanid horses in hunting tournament and investment scenes (Figure 10). Particular attention was paid to the image of individual elements-manes, eyes, nostrils. Numerous horse's ornamentation. Here are the round pendants, fringe, and original shape of the saddle. There are bandages on the horse's legs. The tail of the horse according to Sasanian tradition is in a knot with ribbons. On the whole, the horse's jewelry exactly repeats the elements well known for many plates and reliefs.

Equestrian statue in contrast to the image of the horse looks fragile. The head of the horseman is decorated with Sasanian type crown with a crescent. The crown is three consist of the three stage, at the base two rows of jewelry are specially highlighted, apparently imitating the precious stones which as it known adorned the crowns of Shahanshah and princess. The hairstyle is interpretented in the form of the way lines. 


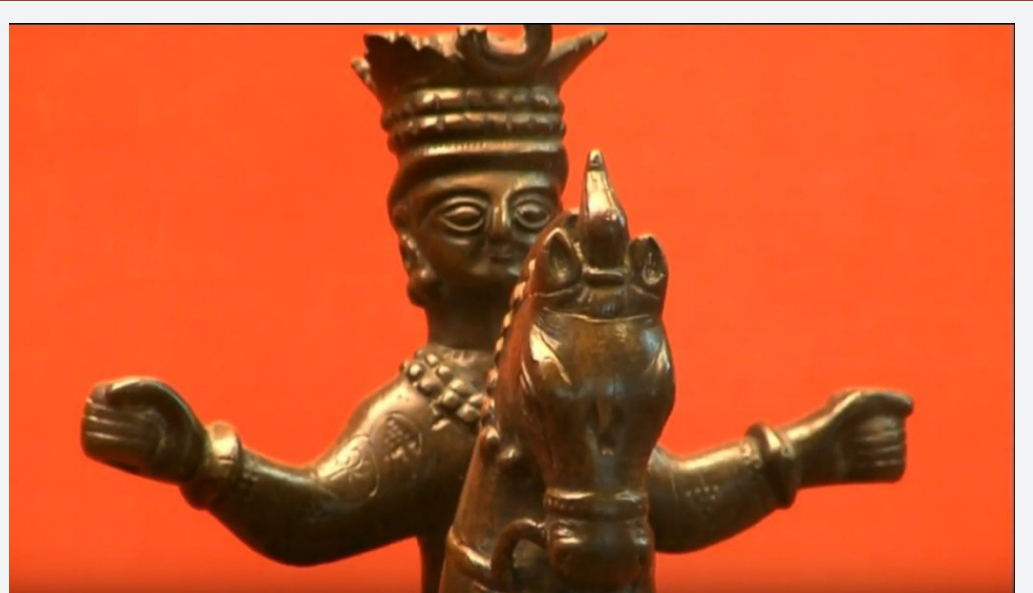

Figure 1: Fragment of the bronze incense burner cameo from the documentary movie about Hermitage the hall of Orient culture.

The hair's combed under the crown and fastened with a special clasp. The equestrian statue's face is smooth without beard with a clear model of individual elements. The earring in form of a ring with two spherical pendants, dressed rider in a caftan.

The decoration of the clothes consists of a vine with leaves and bunches. There is a belt and lower part of the caftan is decorated with rows of depressed points apparently imitating pearl plating. On the back, there is a special engraved lines depict sacred ribbons an attribute in the image of Sassanid rules. The horseman's arms are set aside and clenched into the fist. On the both hands are bracelets. Legs are presented schematically with high boots on the legs.

\section{Comparative Analysis of the Bronze Incense Burner in the Form of Equestrian Statue's Studies}

As it was mentioned that researches who referred to this unique monument have no consensus in regarding to the identity of this equestrian statue. The most wide spread received it is opinion of Trever K. V. about of bronze incense burner personifies the image of Albanian prince from the genus of Mehranid Javanshir (636-669). Trever KV argues her assumption with generating fact that bronze figure of equestrian statue does not match to the well-known portraits of the king-riders. The horseman's robe is unusual, the hairstyle is peculiar, the earring differs from the earring of Sassanid kings, knowing us the images from the plates and coins.

Trever KV was also worried about rider's absence of the beard and mustache, for all almost in every Sassanid portraits images having the classic style it is the beard and mustache. Examining the horse's figure, the scientist errancy notes that in spite of the close to Sasanian type, the master did not find the purpose of the many elements for the horse decoration. Based on her opinion, Trver KV concludes that it is not Sassanid king it is the other person in the crown. In searching for this personality leads Trever to idea of the image of Jevanshir Mehranid. Such assumption is argued by the fact of elements relating to the rider's clothing to some extent coincide with the message by Movses Kaghantvatsi.

Armenian author of the work Caucasian Albania (Patmut'iwn Aluanic) informing that for successful battle against Arabs army,
Sassanid Shah Yazdegerd III ( 632-651) honored to Javanshir Mehranid "...the high ranks, CaucsasiaN Albanian prince was belted with gold belt, humbled with pears, hung the sword, was given the bracelets on his head, bandages and many strings of pearls around his neck, with the gold embroidery". According to her opinion, all of these items are on the bronze figurine. Trever KV regards the image of lions as the blazon of Mehranid Javanshir "...as far as his name means on Persian lion", and image of elephant is associated with the message of Movses Kaghantvatsi about the present of elephant to Javanshir from the side of Arab Caliphate.

Another side of opinion about this bronze equestrian statue, states that bronze incense burner is made in characteristic style of the late Sasanian art, it is necessary to research in more detail the argumentation of advanced by the notes of scholars. Definitely not right, Trever KV by noting a withdrawn from the official cannons adopted in Sassanid portraiture. But at the same time, for some reason researchers lost the sight of the one fact. It is stylistically of the bronze incense burner relating to the VII century A.D. this is the periods of the late Sasanian art which is characteristic feature in according to the many researchers including Trever KV who withdrawing the facts of the Persian canons.

The masters didn't constrained by the canon made certain changes to the image of individual elements and details. Consequently to opinions of the other scholar, there is necessary to compare individual elements of the décor art, the style of making bronze incense burner not with Sasanian art but in generally on a slightly narrower basis comparing it with the works art from the late Sasanian period. With such approaching there is no difficult to notice the design features of the bronze incense burner are characteristic of Sasanian art in VI-VII centuries. The image of the similar horseman taking into account with coincidence of many small details. At the least there are three monuments of the late Sasanian art.

Such images of the rider on Sasanian tissue from Russian territory, Chelyabinsk region (Figure 11), image of Khosrow II in Taq-i-Bostan (Figure 12). 

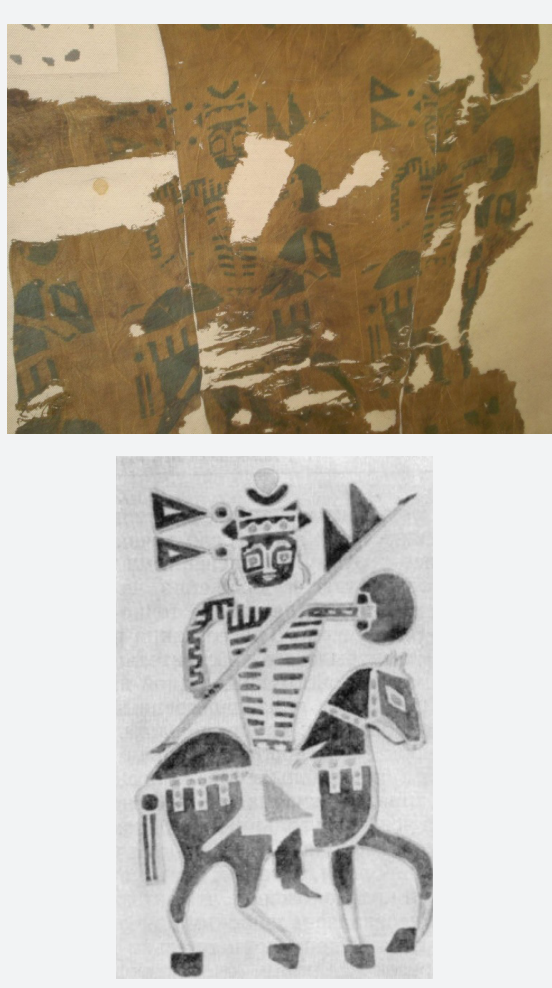

Figure 11: Chelyabinst tissue as the image of Khosrow II.

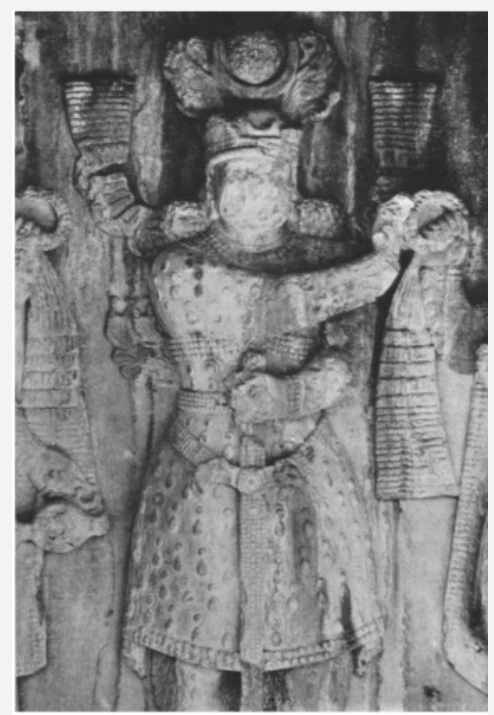

Figure 11: The image of Khosrow II in Taq-i-Bostan.

At these images monuments there is possible to find the similarities as on the bronze incense burner the horse decoration: the ties of the ribbons on the legs of horse, mane shah the same type of saddle and bridle with figured curved bit are treated identically. The floral ornament adoring the side wall of the incense burner pedestal is exactly reproduced on the marked stucco image at the relief of Taq-i Bostan. In Sasanian metal there are finds its analogy and plot of a fox stretching for grapes. We find it on the silver jug of the VII century from collection of Teheran Museum. The lion hunting scene also reveal analogy on another monuments of Sassanid toreutics from the Hermitage collection (Figure 13).
The person deprived of beard and mustache was also not isolated of phenomenon in the art of Sassanid period. Beardless warriors hunting to predatory there are revealing hunt scene on Sasanian vessel of the VII century from Yuldus, Russian region (Figure 14).

The lions on the pedestal are also spoken in favor of Sasanian affiliation of the bronze incense burner. As it is known lion in Persian art is a symbol of the sun. They are symbolizes power and strength also according to this symbol it is the most ancient and sustainable images in the ancient Iranian art. It is hard to agree with one fact that equestrian statute is not characteristic of the Sassanid kings by their shape of earrings. 

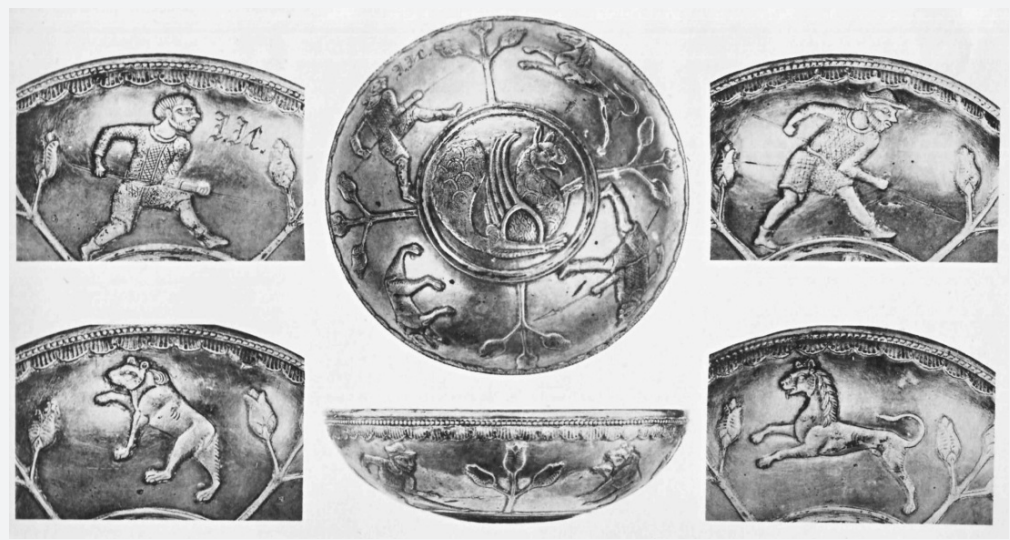

Figure 13: Hermitage collection Bowl. Silver with gilding. Diam $13.4 \mathrm{~cm}$ Two hunters with spears hunt for lions, in the medallion - Senmurv (dog-bird). Until 1895. From the Terek region

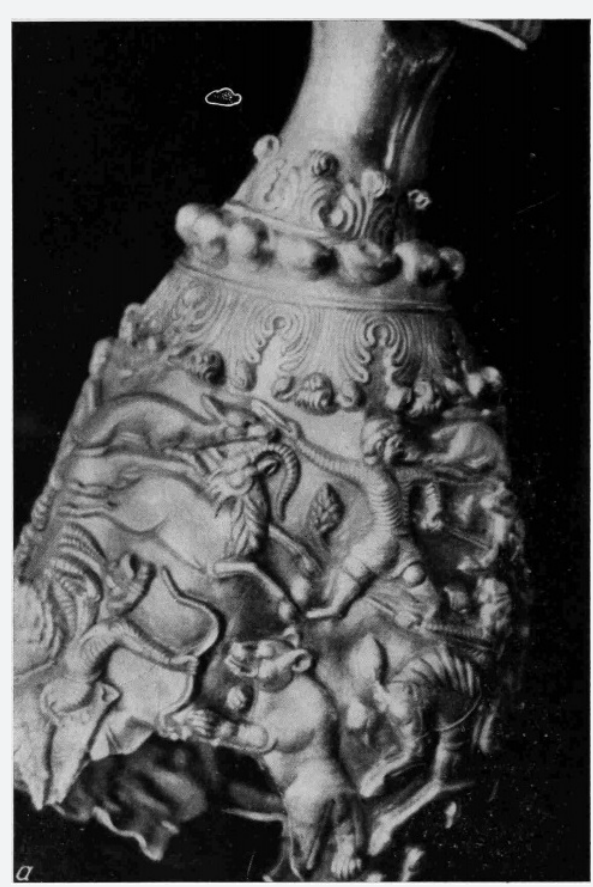

Figure 14: Silver jug general view from s. Yuldus, page 290.

Trever, reports that earrings of the Sasanian king on the plates and lunettes have unchanged shape-small ball from which a large pearl-shaped pendant hangs and the rider's earring on the vessel in the shape of a human head, preserved in National Museum of Georgia indicating to Caucasus Albania origin. However, the earring noted as a typical Sasanian form is characteristic to an earlier period whereas on the monuments of the $\mathrm{V}^{\mathrm{th}}, \mathrm{VII}^{\text {th }}$ centuries. Earring of the same shape prevails, which it is discovered on the bronze incense burner and indicated to vessel. Earring of this type first appear on the coins of Peroz (453-484), then on the all subsequent coin of Sassanid kings (Figure 15).

Exactly same earring is depicted on the plate with hunting scene of Khosrow II. In this way, we are dealing with consistent pattern which is associated with alternatives in iconography of official portraits of Sassanid Kings (Figure 16). No less, vulnerable is erroneous attempt to connect the bronze incense burner with identity of Javanshir Mehranids. According to the message by Movses Kaghantvatsi about awarded Caucasus Albania prince with honorable clothes, weapons, jewelry and a crown was a broad practiced at the Sasanian court to reward vassal rulers for their faithful service.

Armenian historian Yegishe giving description of analogical clothes, weapons, jewelry and talk about the same crown that was awarded to the Syunik prince Vasak for his faithful service to Sassanids. In both cases, it seems there are mentioned about honorable headdress (kulach) which complained by the local rulers and noble holder which became owner. This fact was recorded by historian lived in VI century AD, Procopius of Caesarea (500-570) 
$\mathrm{AD}$ and the inscription of the priest Kartir on Kaaba Zoroaster. Even Movses Kaghantvatsi report that Javanshir Mehranid was respected and honored by the four conquering as the matter of fact wasn't lower than these rulers and no one neglected his power because only he didn't have a crown on his head.
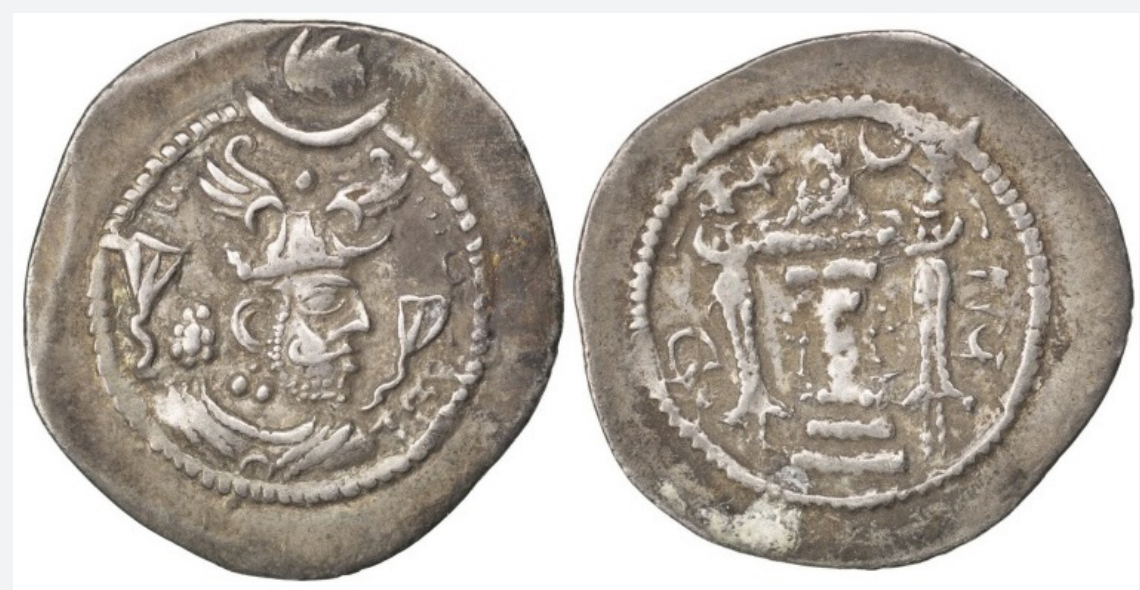

Figure 15:Sassanids, Peroz I (457-484), Drachma, obverse: bust of Peroz I on the right, reverse: altar of fire flanked by two servants, in the field to the left of the fire, a star and on the right a crescent. Göbl 176. (Coins> Greek> Sassanid (II century BC - VII century BC)).

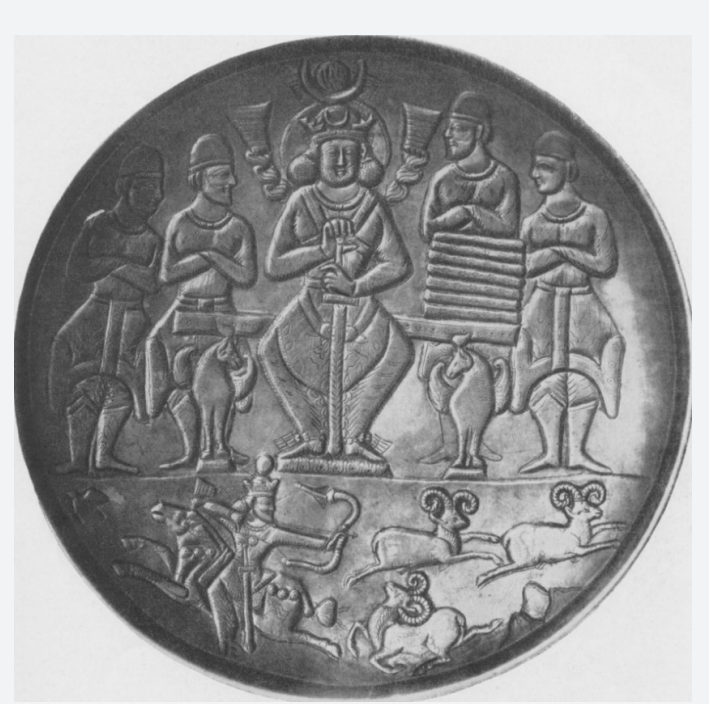

Figure 16:Khosrow II Parviz among his warlord. Below is a prince hunting to a mountain sheep. Silver plate with gilding of the VI century, preserved in Hermitage.

Unlikely that Armenian historian coeval and admirer of Javanshir Mehranid, would have begun to focus on such fact if Javanshir won Sasanain type crown. There are should stay on the one incorrect fact which is connected with the image of elephant. Based on the assumption of another scientist, about that on the incense burner depict elephant gifted to Javanshir Mehranid by Arab Caliph there are the following conclusion that incense burner was made after fall of the Sassanid Empire and establishment of Arab supremacy to which Javanshir Mehranid forced to submit Caliphate. In these conditions such experienced and farsighted politician Javanshir would hardly officially emphasize his closeness to deposed Sasanian rulers. Thereby, the argument of researchers who seen in the incense burner the image of Caucasian Albanian prince Jevanshir Mehranid was a quite assailable and without substantional grounds for revising the conclusion Orbeli IA notes "both in general appearance and details of dress, this figure is extremely close to Sasanian relief on the rocks and at the same time to some images on the silver plates". All above mentioned speaks in favor of this incense burner indicate that this is one of the late Sassanid king. To identification the image practically hard but some conclusion can be drawn based on the shape and details of equestrian statue's crown.

As it known Sassanid kings used have individual crowns, but at the same time, later kings did not infrequently introduced elements of insignia of their predecessors into their crowns. The crown of Pros at the base decorated with one row of gemstones next 
subsequent king like on the incense burner feature in two rows. Moreover, if Peroz's coin with this type of the crowns are usually silver issued for many years in the mass of quantity then for Kavad I, Khosrow I and Khosrow II Parviz crowns only appears in gold dinars the issue were limited to one or two years. On the back side of these coins, there are scene emphasizing special feature of their issue associated with a particular event. On the crown of Kavad I and Khosrow I are "sacred" ribbons that are absent on the dinars of Khosrow II. There is no ribbon on the crown of the incense burner.
Therefore, closest to the crown on the incense burner, both in shape and in the interpretation of individual elements is the crown of Khosrow II Parviz.

Taking in account that incense burner stylistically refers to the fabric of the VI-VII centuries as well as the coincidence of the many elements of the image of KhosrowII in Taq-i-Bostan with the incense it is likely that monument depict KhosrowII. Incense burner could be made in the year of release with special gold coins and therefore they have the same type of the crown (Figure 17).
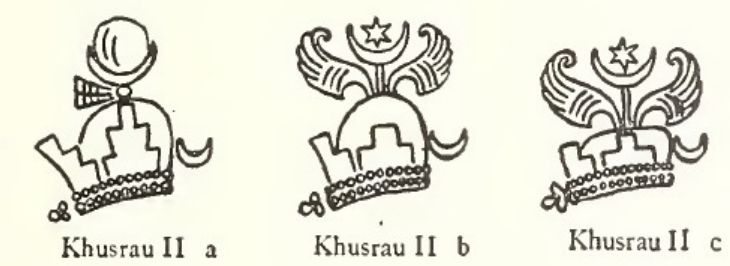

Khusrau II c

Figure 1: Erdman K. Die Entwicklung der Sasanidische Krone // Ars Islamica// XV-XVI, 1951 p.86-124.

\section{Conclusion}

In this article there was reviewed bronze incense burner relating to the early medieval Sassanid Empire, toreutics art found from Azerbaijan and besides the item comes from burial monument firmly dated to this period and alongside with it firmly was identification the bronze equestrian statue image is the king Khosrow II Parviz. Undoubtedly increased their historical importance because incense burner in contradiction to randomly found items to a certain extension materialize written information sources on the important and local production of toreutics in early medieval Iran and Azerbaijan. However, it is obviously that currently available material allowing us to fully illuminate the main role and the place of Sassanid metalwork in early medieval preIslamic period of Azerbaijan as the Persian art heritages.

\section{Acknowledgement}

None.

\section{Conflict of Interest}

No conflict of interest

\section{References}

1. (1909) East Silver Atlas of Ancient Silver and Gold Plate. Publications of the Imperial Archaeological Organization - St. Petersburg.

2. Archeoloque Sovetique (1977) Silver vessel from Yuldus (Kurgan region), Shlyakhova V.I., No.4.
3. Erdman K (1951) Die Entwicklung der Sasanidische Krone. Ars Islamica 15(16): 87-123.

4. Göbl R (1971) Sasanian Numismatics. Wurzburg.

5. Thomson RW, Greenwood T (1999) The Armenian History Attributed to Sebeos, translation and notes historical commentary and J. Howard Johnston with, Liverpool, p. 31.

6. Smirnov YI (1909) Vostochnoye serebro, -SPb, pp. 288.

7. Orbeli IA, Trever KV (1935) Sasanidskiy metal-L.

8. Trever KV (1959) Ocherky istorii I kulitury Kavkazskoi Albanii, M-L.

9. Lukonin VG (1977) Iskustvo Drevnego Irana, M.

10. Orbeli IA (1922) Vremennaya vystavka Sasanidskikh drevnostei II, p. 13.

11. https://commons.wikimedia.org/wiki/File:Taq-e_Bostan-Khosro_ Parviz.JPG

12. Howard Johnston James (2010) Khosrow II, Encyclopaedia Iranica.

13. Ierusalimskaya AA (1969) Chelyabinskaya tkani-TSE.

14. Kinjalov RV, Lukonin VQ (1960) Pamyatniki kulitury Sasanidskogo Irana-L.

15. Kinzhalov RV, Lukonin VQ (1960) Pamyatniki Sasanidskogo Irana-L. Publ. Hermitage, illustration IX.

16. (2015) La Perse Antique, Philip Huyse, Belles Letters.

17. Lukonin VQ (1969) Kulitura Sasanidskogo Irana-L, pp. 217-218.

18. Paola Orsatti (2006) Kosrow a Sirin.Encyclopaedia Iranica. The Hamsah Quintet by Gamali Reply to Nizami Between the Timurids and the QaraQoyunlu. Oriente Moderno 11: 522-524.

19. Lukonin VQ V Khosrow Shahname- Drevniy i raneye srednevekoviy Iran. 